\title{
Krüger, J S Along Edges - Religion in South Africa: Bushman, Christian, Buddhist
}

Pretoria: University of South Africa. 368 Pages. Price: R69.98

\section{Reviewer: Prof Eméritus Herman C Waetjen (Graduate Theological Union, Berkeley)}

This book is a bold venture in its exploration of a new syncretistic religion. Its leamed author sets out to examine religious rememberings and visionings in the historical and socio-cultural context of Southern Africa in order to offer an intellectual prolegomenon to a South African spirituality for a reconstitution of religion and religious studies in South Africa. To achieve that, as he says, “... we are driven back into a genealogy of religion. Indeed, to experience healing in a time of epochal transition, ... we need contact with the earliest inhabitants of this land. To find and give expression to an as yet none-existent, new and unique experience, we need to return to the old. The quest for the roots of South African religion implies reflection on the origin of religion as such, including the reconstruction of its very basics, not only in the chronological but also in the ontological sense: how the various historical religions relate to the human quest for meaning!" Krüger maintains that the deepest level of crisis in South Africa is religious, and with a Rousseau-like orientation he combines personal reflection and empirical scholarship in order to explore the spaces between religions: Christian, Buddhist, Bushman, for the purpose of engendering a provisional synthesis of a contextually relevant, pluralistically conditioned religion. His investigation vis-à-vis the binary opposition of culture versus nature favors the latter term, nature, and is heavily weighted toward the naturalism of the aboriginal hunting and gathering Bushmen. Nevertheless, he does acknowledge that "Neither naturalism nor culturalism is adequate .... We need a synthesis of cosmology and humanism" ( $p$ 252). And that is the objective of his experimental, exploratory, provisional, and empirically oriented reflections. The critical Christian theology of South Africa during the past 20 years, which was oriented toward the dismantling of apartheid, conveyed few creative religious impulses. A religion in a new key is needed, a religion that communicates an as yet non-existent, new, and unique experience. According to Kriger, that requires a retum to the spirituality of the oldest surviving inhabitants of Southern Africa, the Bushmen or the San people, but also the resources of Christianity and Buddhism.

Kriger begins with the data of experience - not a priori assumptions! - from which metaphysical and religious statements may be elicited. Religion and naturalistic empiricism are to be united in order to draw the radical depth dimension of the divine into the realities of everyday life and accordingly transform the threatening chaos into a meaningful cosmos. Objectivity is essential for this enterprise, but objectivity (that) is established at the heart of subjectivity. What is required is not a personal striptease, but awareness on the part of the investigator of his or her personal input into the seeing of the facts. Theory and theorising are indispensable for the understanding and explanation of a religion. The encounter and the dialogue that occur between the investigator and the representatives of what is being investigated require the differentiation of three kinds of understanding: existential, insider (participant) and outsider. The necessary prerequisite of relating two or more religions in order to achieve a cogent synthesis involves the constraint of maintaining the historical uniqueness of each as a growing organism. Validity is determined by coherence with respect to propositions, established tradition, and the world. After devoting 137 pages to an explication of the presuppositions and methodology of his exploration, Krüger begins at the beginning by tracing the evolutionary development of humankind from hominoids through homo habilis and homo erectus to homo sapiens sapiens. Here the objective is a recovery of the roots of religion; and the religion that he anticipates is a spirituality that integrates mind and matter into two aspects of the same process, and God would be the depth of the dynamic universe, not a separate entity. "For the dialectically related 
dimensions of experience (mind and matter) .... I would use the word God, submitting that key Christian concepts such as creation and the Trinity could be interpreted in these terms, and also that this view may accord with the twin Buddhist doctrines of kamma (order) and anicca/anatta (radical openness). For example, in Christian terms Father is God as the principle of integration, Spirit God as the principle of transcendence, and Son God as the principle of concretisation. Such a dynamic idea of divinity may be reconcilable with evolution as a biological paradigm, an idea propogated by process theology for some decades already" ( $p$ 184). Evil is acknowledged as the most serious problem of all religious thought, and it is defined as the absolute affirmation of existing things, expressed in attitudes of attachment to and desire for them (idolatry) and a denial or repression of transcendence in its various manifestations ( $p$ 191). Three chapters are devoted to a history of the hunting and gathering Bushmen from their earliest appearance in Southem Africa to their eventual devastation as a result of the evils of Dutch and British colonialism. This serves as a background to an excursion into Christian theology which occasions a critique of five books by contemporary South African theologians: David Bosch, Albert Nolan, Willem Saayman, Charles VillaVicencio, and Itumeleng Mosala. None of them does justice to the creative tension between theological adaptation and cultural context, either by neglecting an analysis of the contextualization of their own religious beliefs or an explication of the Christian heritage outside of a context. With that criticism said and done, Kriger arrives at the goal of his exploration: a review of the religion of the early South African hunter gatherers, the Bushmen. The main focus will be "human depth experiences" such as "mysticism, meditation, altered states of contemplation, trance, spirituality, et al," all of which are "regarded roughly as synonyms" (p 274). The model or mandala of mystical consciousness is used to interpret the Bushman style of transforming consciousness. "Biopsychic genesis," "the depth of the person" and "conditionalist negation" are analyzed as forms of cosmic orientation. The deity is imagined in different ways: the creator who is good and helpful but remote, or a god who is close and permits intimate discourse, or even two creator gods, one greater and one lesser, both of whom have wives and children. Their theology, demonology and cosmology are not expressed in dogma but in stories. Although their religion cannot serve as a model of "proto-religion of humankind" "it can speak to us." At the very least it can "remind us of the openness of being".

Krüger ends his book with a brief analysis of "the recurring motif of the circle/spiral in Bushman engravings" as an expression of Bushman religion. A bold venture this book is! Much of it is good and worthwhile reading, above all his presentation of the history and religion of the San people. But the book ultimately fails to achieve its objective. Certain religious realities (mystical consciousness, openness to being - as human depth experiences) are promoted, but no provisional "religion in a new key" emerges. Kriger is guilty of his own critique. He offers no exposition of his own understanding of the Christian heritage, and what he does offer indicates that his understanding of Christianity is very traditional. He might have begun with a critical examination of the Christian faith itself. Is Christianity, in fact, a religion? Is that how the writers of the New Testament understand what they are proclaiming? What is the objective of the Christ, interpreted as both Jesus and the community he inaugurated, in the world, especially in relation to the evil that continues to dominate it? In terms of its basic identity, how can the Christian faith be accommodated to the religion of the Bushmen and to Buddhism in onder to engender a new South African spirituality? With a growing sense of frustration the reader encounters only fragments of Christianity and Buddhism which Krüger finds useful for his attermpt at synthesising a new dynamic naturalistic religion. What in fact are the spaces between these three religions? How can these thresholds be joined to constitute a new synthesis that may offer an alternative vision of the world? Concomitantly, is it possible, in relating two or more religions, to do justice to the historical uniqueness of each as a growing organism in a specific culture? Krüger maintains that the human mind collectively shows diachronically evolved similarities and 


\section{Boekbesprekings / Book reviews}

synchronically present regularities ( $p$ 105). But what are the criteria by which they are determined and validated? And how legitimate are those similarities and regularities that are identified by the human mind as it is structured by socioculturally determined prejudices?

Krüger acknowledges that there is "personal input into the 'seeing' of the facts", but such a differentiation seems to presuppose the reality of facts. Yet facts are only medially perceived, and the act of "seeing" is a projection of "being-in-the-world", which hermeneutically determines all interpretation, as Martin Heidegger maintained. To what extent has Krüger perceived the edges along the three religions by which he wants to rejuvenate religion? How adequate an instrument is empiricism in constituting a religious synthesis that will enable human beings to transcend the sociocultural, economic and political limitations of their world and at the same time to empower them to transform that world so that it may participate in that transcendence? 